\title{
Experiential Learning in Historical Bibliography
}

Anne Welsh, Lecturer in Library and Information Studies, University College London ${ }^{l}$

\section{Introduction}

This paper presents an overview of the role of the educational theory of Experiential Learning within the Historical Bibliography module taught at University College London (UCL) as an option within its Masters in Library and Information Studies. Experiential Learning covers not only the use of practicum within Higher Education, but the acceptance that learning is an individual experience, even within group educational settings, and that it involves a wider range of experience than passively absorbing information delivered by course leaders. In session 2010-11, an exploration of students' learning experience discovered that whereas instructors introduced practical experiences to aid the acquisition of practical skills, students reported that these experiences also had an impact on their learning of the more theoretical elements of the course.

Here we consider the UK curriculum for Historical Bibliography; the curriculum at UCL; and the balance between Bibliography as an academic and a practice-based discipline. We then discuss the concept of Experiential Learning in Higher Education in general and then within the Historical Bibliography module at UCL. Finally, we consider the impact of a study of experiential learning on the curriculum of the UCL module. Throughout this paper, the term 'Historical Bibliography' is used in its widest sense, standing for the wider discipline of Bibliography, not in its strictest, narrowest sense of the history of 'the materials and the production of the book and its subsequent dissemination.'2 . At UCL we find the use of 'Historical Bibliography' as a module name avoids confusion in the minds of prospective students (all of whom have first degrees in non-LIS disciplines) between Bibliography (the discipline), bibliography (the list of citations required in an essay), and Bibliometrics (the study of citation practice).

\section{The Curriculum}

\footnotetext{
1 Correspondence to: Anne Welsh, Department of Information Studies, University College London, Gower Street, London WC1E 6BT. a.welsh@ucl.ac.uk

${ }^{2}$ Lloyd Hibberd, "Physical and Reference Bibliography," The Library, s5-XX (2) (1965): 126.
} 
UCL is one of four UK universities offering credit-bearing courses on Bibliography or Rare Books Librarianship more widely. Aberystwyth University offers two courses by distance, which can be taken as part of a Masters degree or as stand-alone short courses. Because the courses are offered as distance learning modules, the eligibility criteria point out that students 'should ideally have access to a rare books collection, however small. ${ }^{3}$ University of Dundee offers a module entitled 'Understanding and Managing Rare Books' within its Master of Literature (MLitt) in Archives and Records Management. ${ }^{4}$ The University of London has, over a number of years, established the London Rare Books School (LRBS), 'a series of fiveday, intensive courses on a variety of book-related subjects. ${ }^{5}$ Credit from the courses can be used towards the MA in the History of the Book from the Institute of English Studies; can be transferred to other Masters programmes in the UK and elsewhere; or can be accumulated at the LRBS to gain a Postgraduate Certificate or Postgraduate Diploma in the History of the Book. ${ }^{6}$

UCL's Historical Bibliography module is available as a short course ${ }^{7}$ taught alongside Masters students. Although available to students taking other modules (including the Master of Research (MRes) in Library, Archive and Information Studies for mid-career professionals), ${ }^{8}$ within the context of 'heritage librarianship' the main programme of interest is the MA in Library and Information Studies (MA LIS). Within the UK setting, the usual route to qualification as a librarian consists of a first degree (usually a Bachelors in England and Wales or four-year Masters in Scotland), followed by work experience as a Library Assistant, followed by the MA LIS. Finally, once employed as a professional librarian, many people complete the chartership scheme of the UK professional body, CILIP (Chartered

\footnotetext{
3 Aberystwyth University, "Rare Books Librarianship 1," last accessed 9 June 2012, http://www.aber.ac.uk/en/postgrad/postgraduatecourses/distancelearning/infostudies/rare_books_librarian_pg1_cpd/

${ }^{4}$ University of Dundee, "MLitt in Archives and Records Management," last accessed 9 June 2012, http://www.dundee.ac.uk/cais/arm/programme_structure.htm

${ }^{5}$ University of London School of Advanced Study Institute of English Studies, "London Rare Books School," last accessed 9 June 2012, http://www.ies.sas.ac.uk/study-training/research-training-courses/london-rare-books$\underline{\text { school }}$

${ }^{6}$ University of London School of Advanced Study Institute of English Studies, "London Rare Books School Fees \& Credit," last accessed 9 June 2012, http://www.ies.sas.ac.uk/study-training/research-training-summerschools/london-rare-books-school/fees-credit

${ }^{7}$ UCL Department of Information Studies, "Short Courses," last accessed 9 June 2012, http://www.ucl.ac.uk/dis/taught/shortcourses

${ }^{8}$ UCL Department of Information Studies, "MRes in Library, Archive and Information Studies," last accessed 9 June 2012, http://www.ucl.ac.uk/dis/taught/pg/mres
} 
Institute of Library and Information Professionals). ${ }^{9}$ The MA LIS is, therefore, the usual entry-level qualification for professional librarians, and, in common with many other countries, although taught within Higher Education, we commonly talk about attending 'library school' when discussing time spent studying for the MA LIS.

The MA LIS curriculum at UCL consists of six core modules, two optional modules, and a dissertation (thesis). The core modules are:

- Cataloguing and Classification 1

- Collection Management and Preservation

- Information Sources and Retrieval

- Introduction to Management

- Principles of Computing and Information Technology

- Professional Awareness (consisting of a work placement, case study and exam)

Historical Bibliography is one of the optional modules reflecting the wide range of roles to which graduates of the programme aspire after library school:

- Advanced Preservation

- Cataloguing and Classification 2

- Database Systems Analysis and Design

- Digital Resources in the Humanities

- Electronic Publishing

- Historical Bibliography

- Manuscript Studies

- Publishing Today

- Records Management

- Services to Children and Young People

- Web Publishing

\footnotetext{
9 CILIP, "Introduction to Chartership," last accessed 9 June 2012, http://www.cilip.org.uk/jobscareers/qualifications/cilip-qualifications/chartership/pages/chartershipintro.aspx
} 
Students commonly combine an option in Historical Bibliography with Manuscript Studies or Advanced Preservation, but, subject to timetable clashes, it is possible for them to combine options to suit their own interests. Since 2009 the Historical Bibliography / Digital Resources in the Humanities combination has been increasingly popular, and, indeed, in session 201112 Historical Bibliography was also offered as an option in the MA / MSc in Digital Humanities which was launched in September 2011..$^{10}$

In terms of teaching skills for heritage librarians, the core modules provide good coverage of what we might term 'soft skills' - communication, personnel management, professional awareness - and certain modules either teach or at least provide a solid foundation for 'hard skills' required by those managing rare book collections. For example, the Management module teaches and assesses budgeting skills, while Collection Management covers the basics of stock acquisition, maintenance and preservation, and Cataloguing and Classification 1 gives enough of a foundation in general cataloguing principles, the Anglo-American Cataloguing Rules (AACR2), MARC21 and Resource Description and Access (RDA) to scaffold teaching and learning in Descriptive Cataloguing in Rare Materials (Books) $(\operatorname{DCRM}(B))$ within Historical Bibliography and Cataloguing and Classification 2.

\section{Rare Books in Practice}

The MA LIS is both an MA awarded by one of the world's top ten universities ${ }^{11}$ and a vocational course preparing the next generation of librarians for their first professional posts. This means that for us Historical Bibliography is a practice-based discipline, with rare book collections of varying sizes the destination of many of our graduates. Even in the current economic downturn, the summary on CILIP's Rare Books and Special Collections Group website is still an accurate UK picture:

Opportunities to work with rare book and special collections arise in many kinds of libraries. Specialist independent libraries - such as those concerned with law, medicine, astronomy, beekeeping, architecture or accountancy, to name but a few with current material in their subject areas sometimes also have older material, and

\footnotetext{
10 UCL Centre for Digital Humanities, "MA/Msc in Digital Humanities," last accessed 9 June 2012, http://www.ucl.ac.uk/dh/courses/mamsc

${ }^{11}$ QS Top Universities, “QS World University Rankings Overall in 2011,” last accessed 9 June 2012, http://www.topuniversities.com/university-rankings/world-university-rankings/2011
} 
working with this will usually form part of one librarian's responsibilities. In a few cases the stock of a specialist library may fall almost entirely into the special collections category and its care may require a full-time special collections librarian. There are many rare book and special collections in the public library sector which are managed alongside current collections. This applies particularly to local studies collections which frequently hold, for example, unique copies of early local printing and sometimes whole collections (on any subject) gifted by local collectors. Cathedral libraries hold a large amount of early material, including local studies resources. There are also special collections in national libraries and many university and other research libraries, requiring part-time special collections librarians or, in some cases, one or more full-time special collections librarians. ${ }^{12}$

On the first day of this conference, Professor Stam talked about the American Library Association (ALA) and Association of College \& Research Libraries competencies ${ }^{13}$ and identified an emphasis on functions, in which knowledge about the Book is tucked into Collection Development. The UK's Rare Books and Special Collections Group differentiates between 'skills' and 'knowledge' in its Skills of a Rare Books and Special Collections Librarian: Framework, identifying the following as skills (their emboldening):

- historical bibliography and understanding the characteristics of a wide range of formats ...

- preservation issues and practical knowledge relating to environmental control and the safe handling of material being stored, consulted, displayed, photocopied, etc.

- other collection management issues, for example, providing a secure environment for storage and consultation, insurance, loans in/out

- cataloguing of rare book and special collections ... also having an understanding of national and international union and other catalogues as a means of assessing rarity and promoting the library's holdings (for example, knowing how to derive maximum benefit from the English Short Title

\footnotetext{
12 CILIP Rare Books and Special Collections Group, "Careers in Rare Books and Special Collections," last accessed 9 June 2012, http://www.cilip.org.uk/get-involved/special-interest-groups/rarebooks/pages/careers.aspx

${ }^{13}$ Association of College and Research Libraries, "Guidelines: Competencies for Special Collections Professionals," last accessed 9 June 2012, http://www.ala.org/acrl/standards/comp4specollect
} 


\section{Catalogue)}

\section{- - library management systems ...}

- . reference work ...

- methods for promoting the collections, ranging from large-scale digitisation projects to setting out a small selection of items for a visiting group or single potential benefactor ...

- . the basics of market research ...

- $\quad$ presentations ...

- . writing ...

- . fund-raising ...

- project planning and management ...

- . people management ... covering both employed staff ... and volunteers

- legislation and standards ...

- . intellectual property rights ${ }^{14}$

The same document continues (their emboldening):

But in addition to these skills the rare books and special collections librarian also requires knowledge of

- - the collections that he/she looks after in order to identify items to meet specified needs: for example, what would be appropriate exhibits for anniversaries, special occasions, special visitors, etc., or what would provide worthwhile content for digitisation projects, including collaborative projects

- the subject areas of the collections to help interpret them and also to facilitate appreciation of the research value of items in the collections

- - languages, to help manage and research the collections and also to assist users (for example, increasingly users come without any Latin)

14 CILIP Rare Books and Special Collections Group, "Skills of a Rare Books and Special Collections Librarian: Framework," published 2007, http://www.cilip.org.uk/filedownloadslibrary/groups/rbsc/skills\%20of\%20a\%20rare\%20books\%20librarian.pdf 
- $\quad$ related collections of similar material in other libraries, to help appreciate the particular strengths of ones own collections and the possibilities for collaboration

Crucially, this document acknowledges the life-long learning in which heritage librarians engage: 'Many of the skills will be needed from the start when a librarian joins an institution; others will follow in due course, as the librarian acquires more responsibility.' A later document, published in 2010, outlines the need for advocacy of the heritage librarian's skills, in contrast to and complementing the skills of the professional archivist. This highlights the need for professional qualifications and training information handling skills (specific to "the complex features of rare books'); knowledge of collections; and self-promotion in the workplace. In particular, it identifies the responsibility of heritage librarians and archivists 'to highlight the value of rare books and archives. ${ }^{15}$

The curriculum for the Historical Bibliography at UCL was designed against this backdrop, and we continue to monitor the needs of the special collections profession, not only by following the publication of formal documents in the UK and more widely, but also by maintaining close links with colleagues responsible for the management of heritage collections.

\section{Bibliography as an Academic Discipline}

Within the Historical Bibliography module, a balance has to be maintained between equipping students for their life in practice and providing them with the core knowledge of the discipline. We might categorize these activities broadly as:

- Training

- Skills for rare books curation

- How to be a rare books librarian

- Education

○ Bibliography as an academic discipline in its own right

\footnotetext{
15 CILIP Rare Books and Special Collections Group, "Advocating the role of the Rare Books Librarian," published 2010, http://www.cilip.org.uk/filedownloadslibrary/groups/rbsc/advocating\%20the\%20role\%20of\%20a\%20rare\%20b ooks\%20librarian.pdf
} 
- Bibliography as foundational knowledge for rare books librarians

○ Bibliography as foundational knowledge for all librarians

The module aims to provide a suitable level of training, while emphasizing the foundational aspect of Bibliography in the education of heritage librarians. This historical perspective provides students with a wider context for other concerns in $21^{\text {st }}$ century librarianship:

\begin{abstract}
As they have in many other transition periods in book history - from the scroll to the codex, for instance, or from manuscript to print - librarians will have to decide which materials to preserve in their original format, which to transfer to new media, and which to leave behind ... Likewise, they will face the even thornier issue of deciding what new print collections their libraries will build in this increasingly digital era ... Does the printed codex ... still have a role for researchers? ... A grounding in book history can help librarians face these and other issues by presenting past periods of transition in the history of the book, and analyzing how similar problems in those periods were faced and, perhaps, resolved. ${ }^{16}$
\end{abstract}

The academic component of the course comprises an introduction to the different branches of Bibliography. Enumerative Bibliography is highlighted as a useful practical resource for rare book curators and the importance of being able to decipher and understand bibliographies is introduced in the first week of class, which immediately opens the subject out from LIS as the curation and documentation of materials to a discussion of those outside the library community with bibliographic interests, and to the Textual Bibliography that has been the core of Bibliography within the academic community. This allows for the introduction of the concept of the ideal copy. Descriptive and Analytical Bibliography skills are taught, including quasi-facsimile, collation and foliation, supported by classes and reading on the processes of book production (Historical Bibliography in the narrower sense of the term). These processes are set within the wider social context of the History of the Book, following Darnton's model of the Communications Circuit, ${ }^{17}$ and discussing the concepts of the history

\footnotetext{
16 Erik Delfino, "Book History and Librarian Education in the Twenty-First Century," in Teaching Bibliography, Textual Criticism and Book History, ed. Ann R. Hawkins (London: Pickering \& Chatto, 2007), 81 .

${ }^{17}$ Robert Darnton, "What is the History of Books?" Daedalus 111(3) (1982): 65-83.
} 
of technology as innovation versus the history of technology-in-use. ${ }^{18}$ As well as introducing Book History, we also touch on the related disciplines of Digital Humanities and Manuscript Studies, stressing that 'All documents, manuscript and printed, are the bibliographer's province; and it may be added that the aims and procedures of bibliography apply not only to written and printed books, but also to any document, disc, tape or film where reproduction is involved and variant versions may result., ${ }^{19}$

\section{Teaching and Learning Activities}

It should be clear from this overview that the module covers a lot of ground in only 30 hours contact time. Because it is taught at Masters level, and because it is an optional module that tends to attract students who enjoy learning through self-study, it is possible to rely on students to keep up with reading in support of the Book History element. Nevertheless, in designing the current iteration of the module in 2009 , constructive alignment was used to ensure the presence of activities designed for the deep learning in which most students wish to engage but also to have a clear route to success in assessments for those few students who employ strategic learning in the module. In constructive alignment, it is acknowledged that students learn by what they do ('active learning'), Intended Learning Outcomes (ILO) are communicated to them at the beginning of the course, and these form the basis of assessment. $^{20}$

In the Historical Bibliography module, students demonstrate their skills of observation and accuracy and their ability to understand bibliographic descriptions by creating a quasifacsimile of an Early Modern title page, which is worth $30 \%$ of the overall mark. An historical essay is also submitted, from a choice of ten topics, ranging from the theoretical (e.g. 'What is Historical Bibliography?') through Book History (e.g. 'Why was Venice significant in the History of the Book?') to the pragmatic (e.g. 'Whose book is it? What is so important about Provenance?'). This essay is worth $70 \%$ of the overall mark and is graded according to the same standards as any other UCL Masters-level History essay.

\footnotetext{
18 David Edgerton, The Shock of the Old: Technology and Global History since 1900 (London: Profile, 2008).

${ }^{19}$ Philip Gaskell, A New Introduction to Bibliography (Winchester: St Paul's Bibliographies, 1995), 1.

${ }^{20}$ John Biggs and Catherine Tang, Teaching for Quality Learning at University: What the Student Does, $3^{\mathrm{rd}} \mathrm{edn}$. (London: McGraw-Hill, 2007)
} 
Teaching and learning activities are structured in three categories. In-class activities include lectures; practicals (e.g. book-handling, exercises on collation and foliation, cataloguing and binding identification and description); and the assessed quasi-facsimile exercise and practice for it. It is assumed that students will attend all classes. In personal study, students work on their assessed essay and read in support of it and of in-class activities. There is only one essential text, Gaskell's A New Introduction to Bibliography (Winchester: St. Paul's Bibliographies, 1995), but they are expected to know this cover to cover and to supplement it with readings from an extensive reading list according to their interests, the requirements of the essay topic they have chosen, and more importantly, their self-assessed needs in terms of keeping up with in-class activities.

Because students have already completed at least one degree, they are expected to have the self-knowledge to identify when they understand a concept and when they do not. At UCL we operate the standard English 'office hour', in which module tutors make themselves available to students for at least one designated hour a week on a 'drop-in' basis (i.e. there is no need for the student to book an appointment: the tutor is available for any course-related question however large or small). It is expected that students will use the office hour to discuss any individual requirements. Since 2009 , this has ranged from the fairly common 'I'm really interested in this particular area, I've read the books on the suggested reading list, what else do you recommend?' through to the much less common but extremely important 'I was ill on Monday and have gone through the online handouts but can we please go over collation with one of your practice examples because it's hard to grasp just from Gaskell?'

The final category of teaching and learning activities is excursions. We arrange one compulsory excursion that takes place during class time to see a printing press. Until 2012, this was always a visit to St. Bride's Printing Library, where the then Librarian, Nigel Roche, talked students through the printing process, using the Library's range of presses, compositor's trays and type. In 2010-11 we were also able to offer an optional excursion outside class time, to the Bibliography Room in Oxford, where Dr Paul Nash ran a session in which students were able to compose and print their names.

In 2010-11, class time was structured to comprise:

- 10 hours of lectures of lengths varying from 20-40 minutes 
- 8 practicals of lengths varying from 30 minutes to 3 hours (excluding breaks)

- 1 excursion

\section{Experiential Learning}

In the field of Education, the concept of Experiential Learning was first proposed by John Dewey in the 1930s. It encompasses the idea that learning is not solely about the teaching offered: we all learn differently, drawing on our previous experiences. A commonly-used diagram by Kolb shows Experiential Learning as a dynamic process inside a triangle whose three angles are labeled 'Education', 'Work', and 'Personal Development.'21

Kolb's model applies to any learning situation. Within a vocational subject like LIS, it is not only generally useful, but also allows an educational framework that acknowledges that learning does not necessarily start in the classroom - students arriving with years of workexperience bring with them years of learning, and educators need to target these students as well as those to whom concepts are brand new when we raise them in the classroom. The model also allows room for the life-long learning that is so much a part of many library roles, and which was highlighted by the Rare Books and Special Collections Group's documentation on the skills and knowledge of the rare books librarian.

In 2010-11, an investigation was conducted into the learning experience of students on the Historical Bibliography module. Knowing the teaching offered on the module, it set out to explore what the students felt they learned. In the $21^{\text {st }}$ century, when educators are utilizing more and more online learning activities, it was felt particularly important to discover the right balance between direct knowledge transfer (lectures and reading, which is easy to deliver remotely) and active learning (practical activities that can only be experienced physically in real life).

The observations in the rest of this paper highlight the findings related to the education of heritage librarians from a paper-based survey of 31 (100\%) course participants at the end of the module in December 2010; an online survey in April 2011, completed by 16 students (51.61\%); interviews with 7 students (22.58\%) in Summer 2011; and free-form feedback

\footnotetext{
${ }^{21}$ David A. Kolb, Experiential Learning: Experience as the Source of Learning and Development (New Jersey: Prentice-Hall, 1984).
} 
received from students for a presentation-style report on the optional visit to the Bibliography Room in Oxford. A full analysis of the investigation will be published shortly. The observations here are limited to those related to training for competencies and its role within wider education.

\section{Pre-Library School Experience}

Although students must have at least one year's experience working in a library environment to be admitted to the MA LIS course, it is not necessary to have rare books experience to take the Historical Bibliography module. Of the 16 respondents to the online questionnaire, 9 stated they had no professional special collections experience prior to the course, while 7 had worked with rare books in various degrees, including one antique bookseller. Tasks undertaken by members of the group included cataloguing; preservation; reference work; providing access to materials; and carrying out research for a cataloguing project. Interviewee 4 is representative of the more experienced students on the course:

Chronologically, working forwards, I started in a cathedral library which was a mix of modern lending library, manuscripts, early printed books and incunabula, ... a large academic library, dealing with law books from 1800 onwards ... dealing with preservation issues.

By the time the interview was conducted, she had also undertaken her two week MA LIS work placement in the Special Collections Department of a large academic library.

Whatever their experience-level, just under half (44\%) the students on the module were strongly motivated, with $31 \%$ students in the online questionnaire checking the box that the module was a reason they chose the UCL MA LIS course and a further $13 \%$ checking the box that the module was the main reason they chose UCL. In free-text answers, 12 of the 16 respondents to the online questionnaire offered reasons that included an element of personal interest when asked why they chose Historical Bibliography as an option:

It seemed like a course that I would not be able to take anywhere else. It also seemed to be a little more academic in nature than some of the other options, which appealed to me (Respondent 15). 
In answer to the question 'Do you want to work in Special Collections?' 8 respondents to the online questionnaire checked the box for 'maybe'; 6 for 'Yes' and 2 for 'No - I took the course for interest.'

\section{The Practical Elements of the Module}

In the paper questionnaire in December 2011, 27 students said the balance of practicals to lectures was right, while 3 said there were too many lectures and 1 said there were too many practicals. In the online questionnaire, it was clear from free-text answers that those who liked the practical element felt very strongly about it:

I think that the hands on sessions with the books were vital and really brought the subject to life. I think that objects have an immediacy that makes the tactile aspects of the course both interesting and memorable. (Respondent 6)

However, there was great disagreement in which of the classes were most successful. This was most marked in response to the bindings session, which topped the paper-based questionnaire's results for both favourite and least favourite class. The free-text comments elucidate some reasons:

The binding class frustrated me because I love the subject and felt that others who may not have seen binding material before - or done some binding themselves (as I have) may have been a bit overwhelmed (Student 3).

I enjoyed the bindings class - enjoyed the challenge of trying to identify and describe the form of bindings. (Student 9).

Collation was chosen as least favourite practical by 3 students but favourite practical by 5 students. Again, the free-text answers are helpful in unpacking this:

Collation, because it was quite hard to get to grips with, but that's not a criticism of how it was taught! (Student 5). 
Collation - has been really useful in my job! (Student 29).

These answers are also indicative of the level of self-awareness students possess. Degreeeducated and with some experience working in a library setting, it is hardly surprising that they show appreciation that learning is not always an enjoyable experience but that some unpleasant things can be important to learn.

Students also showed their awareness of learning in their descriptions of the optional excursion to the Bibliography Room in Oxford. As Heather McKenna summarized in her contribution to the online slideshow of the visit, this was 'An exciting opportunity to get hands on experience of traditional printing processes that we had been taught during the course, ${ }^{22}$ or, in the more educational parlance of Respondent 3 in the online questionnaire

It was really helpful to use this kind of kinetic learning opportunity to gain an insight into the printing process. As librarians we are learning to conserve books as material sources of social history, not just repositories of intellectual knowledge, so it was revealing to put oneself into the position of the nameless compositors and printers who played such a crucial role in the production of texts.

In reading the students' responses to questionnaires and their free-text contributions to the online slideshow, it was apparent that while the Historical Bibliography module instructors had introduced practical learning mainly with a view to aiding the acquisition of practical skills, students were expressing benefits from practical learning in gaining more theoretical knowledge. Several students formed connections between the historical experience of the printers and our experiences today:

Things that we had to think carefully about such as spacing are still relevant today in the way we present information. (Frances Cassidy) ${ }^{23}$

In the digital age we are so used to seeing text printed and reproduced effortlessly, bit the technology is hidden inside computers and printers. Having actually printed

\footnotetext{
${ }^{22}$ Anne Welsh, "Visit to the Bodleian Bibliography Room, 10 March 2011," http://www.slideshare.net/AnneWelsh/bib-room slide 7

23 "Visit to the Bodleian Bibliography Room," slide 6.
} 
something myself, I have a greater appreciation for how the letters actually ended up on the page. (Helen Doyle) ${ }^{24}$

Other students expressed an increased understanding of processes they had heard about in class or read about in books, as in these answers from the online questionnaire:

It put into perspective the detailed work that went into printing a book. (Respondent 8)

The way the matrix worked, finally, finally clicked for me seeing one in my hand with the mould in the other. No matter how many times I read about the parts of type I never got how all the pieces were put together and how the casting process worked. (Respondent 4)

I learnt about the human involvement in printing. I learnt what it felt like to be in a printing-house, compositing and using the press, rather than learning just about the mechanics. It is easy to say 'then the compositor composed the text' but that gives you no indication of how long it took, how small the pieces of type were or how hard the justification of the text was! (Respondent 9)

Respondent 9's comment on learning how something felt indicates the importance that they set on experience as a tool to understanding and also highlights the individual nature of learning. Slide 3 of the online report provides visual evidence that when an instructor is teaching a group, each student is experiencing learning on their own. In the picture on the bottom right, the group are watching Dr Paul Nash demonstrate the printing of a sheet. While six of the students are smiling, enjoying the demonstration, two of the students have expressions that show uncertainty (far left) and displeasure (third left). When we saw the picture, and asked them, separately, what they were thinking, they each reported noticing that the alignment was slightly out. While the other students, who were seeing a printing press working for the first time, were concentrating on the overall experience and listening to the commentary, the two unsmiling students had enough pre-existing knowledge of the process to identify a minor error. Moments later, Paul Nash himself noticed the sheet was misaligned, and ran another through the press, which reinforced the learning of the two observant

24 "Visit to the Bodleian Bibliography Room," slide 13. 
students. In this photograph, the camera has captured the different experience of the students in the group.

Having been asked to submit a maximum of three sentences summarizing their two hours at the Bibliography Room, the comments students offered suggested subtle differences in their learning experiences. Sian Prosser illustrates the distinction between knowing something and understanding it in her comment, 'In the Bibliography Room I handled heavy machinery and leaden pieces and it was not until I had to proofread upside down and back to front in order to create a properly composed sheet of print that I began to understand the complexity of the process. ${ }^{25}$ For her, the physicality of the activity aided understanding. Joanne Maddocks' comment revealed that her experience was rooted in some of the core concepts in Bibliography that she was learning on the course, most notably the differences between editions, impressions and states of printed books:

Having the chance to do some compositing ourselves really showed how many decisions about spelling, word breaks and spacing were made by the compositor in the course of his work. This and the number of errors caught in the proofreading stage of even our small sheet really brought home the inevitability of differences between editions and the effect these would have had on the way the text was interpreted by readers. ${ }^{26}$

The progress of the students from knowledge to synthesis and evaluation indicated by their brief synopses of their excursion is reminiscent of Bloom's Taxonomy. In its classic form, this is shown as a pyramid with 'lower order learning' at the bottom and 'higher order learning' at the top. In any experience, an individual might progress from knowledge, at the bottom, through four stages - comprehension, application, analysis and synthesis - to the highest order of learning, evaluation. Bloom's Taxonomy has undergone many revisions and developments since its original publication in 1956, with some commentators arguing against its hierarchical structure, but the original pyramid diagram remains the dominant form of the Taxonomy in the Educational literature. ${ }^{27}$

\footnotetext{
25 "Visit to the Bodleian Bibliography Room," slide 10.

26 "Visit to the Bodleian Bibliography Room," slide 12.

${ }^{27}$ Robert J. Marzano and John S. Kendall, The New Taxonomy of Educational Objectives, $2^{\text {nd }}$ edn. (Thousand Oaks, CA: Corwin, 2007), 2-8.
} 
In the few quotations from students here, it is clear that the learning outcomes are more complex that those first envisaged. Within the presentation-style report and the answers to the online questionnaire, students demonstrated analysis of their experience and the desire to synthesize it with existing knowledge, not only of printing processes but also of their impact on word processing. Student comments also indicated their personalization of the information as they evaluated it and integrated it in their world view:

For me, the most valuable part of the visit was being reminded that technology has always been vital to the dissemination of ideas. There has been a massive shift from the use of the type mould and typeset plate to the use of Word and programming languages for web publishing, but that only made me realize how much potential there still is for things to change later on. (Jennifer Howard). ${ }^{28}$

Interviews with the students about their practical experiences within the module provided more evidence of higher order learning achieved through active learning. Some students expressed a decided preference for learning through experience as opposed to reading or listening:

I've always felt that practical elements are really important in things because I don't like dealing with abstract concepts ... I think it's essential to put the theory into practice and to do hands-on things. I suppose that is partly the way I learn. I do need to do things to learn them effectively. (Interviewee 7).

I think practical learning more than any other type encourages people to talk to each other, so that helped me to get my head round it, because if I'm talking about it, I'm asking questions and I can understand it more. (Interviewee 5).

One part-time student reported the transfer of knowledge from the classroom to the workplace:

I think having the practical experience of working with the books is what gave me the confidence to look at the books that I've got to work with now, not as a scary thing ...

28 "Visit to the Bodleian Bibliography Room," slide 15. 
I've gotten to the point where I can look at something and have a reasonable idea of what it is and where it's come from, which means that I can then go on and start cataloguing it. (Interviewee 1).

Gaining professional confidence to handle books and work with them was one of the main intended learning outcomes for the module. Another part-time student demonstrated high order learning in evaluating his knowledge from the course and using it appropriately in his workplace:

I was using the techniques I had learned for the Western Book to apply to the Middle Eastern Book ... there's a physical difference, but in terms of printing whatever's been happening in the West was happening in the Middle East, but in a different time frame. (Interviewee 3).

The clearest example of higher order learning came from a student who took the module purely out of interest and expressed the impact of her learning experience on her world view:

Working in a public library setting and knowing the history behind what we were putting onto the shelves really made me aware of my place in the information chain ...

I'm quite knowledgeable on how to look at a website and decide whether it's authoritative, and so seeing the issues now trying to deal with websites and how you can look back and see how all that evolved, when the printed book came about, it's the same issues ...

Making people aware that it's a device for transferring information just as much as the computer is nowadays ... I don't know if that's a practical thing, but that's something that I would say I got out of the course. (Interviewee 2).

\section{Conclusions}

The results of the exploration revealed that practical activities have deeper impact on the student learning experience than educators teaching the Historical Bibliography module appreciated when they designed its curriculum. The predicted direct relationship of doing practical activities in order to learn practical skills, such as book-handling, collation and identification of different binding materials, was borne out by the study. However, it also 
revealed that active learning contributed to students' understanding of more theoretical concepts in Bibliography such as differences between editions, impressions and states. Beyond this, evidence was found of the individual nature of experiential learning and, as students progressed from knowledge and comprehension to analysis, synthesis and evaluation, it became clear that learning from the course was being integrated not only into their practice at work but, in some cases, into their world view.

The study took place at an important time in the development of the module. In September 2011 the first cohort of students on UCL's new MA / MSc in Digital Humanities (DH) were offered the course as an option. Before undertaking this exploration of experiential learning in Historical Bibliography, the course tutors had been discussing the appropriate balance of practical to theoretical activities when the student body became a mix of those who needed to acquire special collections curatorial skills and those who were studying for entirely academic reasons. Discovering the benefits of the practicum to the acquisition of theoretical knowledge encouraged its retention in the module, with only a small reduction in the rare books cataloguing element. Some cataloguing was retained, with further practice transferred to the optional module Cataloguing \& Classification 2, which is taught in the Spring Term. MA LIS students from the Historical Bibliography module were encouraged to attend the session in Cataloguing \& Classification 2 that covered rare books cataloguing. In fact the small proportion of cataloguing practice that was removed from the Historical Bibliography module was replaced with a practical activity on types of printing for book illustrations, and so the balance of practical to theoretical learning remained the same.

As technology makes it increasingly possible to offer elements of LIS courses online, it is becoming more important for educators to consider their modules' modes of delivery. On the evidence of this small study, it can be argued that a proportion of the education of heritage librarians must continue to be conducted using face-to-face, practical activities. It would be timely to conduct a study with a larger cohort of students into exactly which elements of learning are most beneficial to the widest range of people when offered as practicum. While there is a common-sense element to this question (for example, it is clear that one can only learn how to handle rare books by actually doing so), this small study at UCL indicates that experiential learning has the potential to benefit the study of more theoretical branches of 
Bibliography, and it would be interesting to pinpoint areas in which student experience can be enhanced by active learning activities.

\section{Works Cited}

Aberystwyth University. "Rare Books Librarianship 1,” last accessed 9 June 2012, http://www.aber.ac.uk/en/postgrad/postgraduatecourses/distancelearning/infostudies/rare_books_librarian_pg1_cpd/

Association of College and Research Libraries. "Guidelines: Competencies for Special Collections Professionals," last accessed 9 June 2012, http://www.ala.org/acrl/standards/comp4specollect

Biggs, John and Catherine Tang. Teaching for Quality Learning at University: What the Student Does, $3^{\text {rd }}$ edn. London: McGraw-Hill, 2007.

CILIP. "Introduction to Chartership," last accessed 9 June 2012, http://www.cilip.org.uk/jobs-careers/qualifications/cilipqualifications/chartership/pages/chartershipintro.aspx

CILIP Rare Books and Special Collections Group. "Advocating the role of the Rare Books Librarian," published 2010, http://www .cilip.org.uk/filedownloadslibrary/groups/rbsc/advocating\%20the\%20role \%20of\%20a\%20rare\%20books\%20librarian.pdf

CILIP Rare Books and Special Collections Group. "Careers in Rare Books and Special Collections," last accessed 9 June 2012, http://www .cilip.org.uk/get-involved/specialinterest-groups/rare-books/pages/careers.aspx

CILIP Rare Books and Special Collections Group. "Skills of a Rare Books and Special Collections Librarian: Framework," published 2007, 
http://www.cilip.org.uk/filedownloadslibrary/groups/rbsc/skills\%20of\%20a\%20rare\% 20books\%20librarian.pdf

Darnton, Robert. “What is the History of Books?” Daedalus 111(3) (1982): 65-83.

Delfino, Erik. "Book History and Librarian Education in the Twenty-First Century." In Teaching Bibliography, Textual Criticism and Book History, edited by Ann R. Hawkins. London: Pickering \& Chatto, 2007.

Edgerton, David. The Shock of the Old: Technology and Global History since 1900. London: Profile, 2008.

Gaskell, Philip. A New Introduction to Bibliography. Winchester: St Paul's Bibliographies, 1995.

Hibberd, Lloyd. "Physical and Reference Bibliography," The Library, s5-XX (2) (1965): 124-134.

Kolb, David A. Experiential Learning: Experience as the Source of Learning and Development. New Jersey: Prentice-Hall, 1984.

Marzano, Robert J. and John S. Kendall, The New Taxonomy of Educational Objectives, $2^{\text {nd }}$ edn. Thousand Oaks, CA: Corwin, 2007.

QS Top Universities, “QS World University Rankings Overall in 2011,” last accessed 9 June 2012, http://www.topuniversities.com/university-rankings/world-universityrankings/2011

UCL Centre for Digital Humanities, "MA/Msc in Digital Humanities," last accessed 9 June 2012, http://www.ucl.ac.uk/dh/courses/mamsc

UCL Department of Information Studies, "MRes in Library, Archive and Information Studies," last accessed 9 June 2012, http://www.ucl.ac.uk/dis/taught/pg/mres 
UCL Department of Information Studies, “Short Courses,” last accessed 9 June 2012, http://www.ucl.ac.uk/dis/taught/shortcourses

University of London School of Advanced Study Institute of English Studies. "London Rare Books School," last accessed 9 June 2012, http://www.ies.sas.ac.uk/studytraining/research-training-courses/london-rare-books-school

University of London School of Advanced Study Institute of English Studies. "London Rare Books School Fees \& Credit," last accessed 9 June 2012, http://www.ies.sas.ac.uk/study-training/research-training-summer-schools/londonrare-books-school/fees-credit

Welsh, Anne (comp.). "Visit to the Bodleian Bibliography Room, 10 March 2011," http://www.slideshare.net/AnneWelsh/bib-room 